Article

\title{
The Agency of the Displaced? Roman Expansion, Environmental Forces, and the Occupation of Marginal Landscapes in Ancient Italy
}

\author{
Elisa Perego ${ }^{1,2, *}$ and Rafael Scopacasa ${ }^{3,4, *}$ \\ 1 Institut für Orientalische und Europäische Archäologie, Austrian Academy of Sciences, \\ A 1020 Vienna, Austria \\ 2 Institute of Archaeology, University College London, London WC1H 0PY, UK \\ 3 Department of History, Federal University of Minas Gerais, Belo Horizonte 31270-901, Brazil \\ 4 Department of Classics and Ancient History, University of Exeter, Exeter EX4 4RJ, UK \\ * Correspondence: lisa.Perego@oeaw.ac.at (E.P.); r.scopacasa@exeter.ac.uk (R.S.)
}

Received: 1 February 2018; Accepted: 16 October 2018; Published: 12 November 2018

\begin{abstract}
This article approaches the agency of displaced people through material evidence from the distant past. It seeks to construct a narrative of displacement where the key players include human as well as non-human agents-namely, the environment into which people move, and the socio-political and environmental context of displacement. Our case-study from ancient Italy involves potentially marginalized people who moved into agriculturally challenging lands in Daunia (one of the most drought-prone areas of the Mediterranean) during the Roman conquest (late fourth-early second centuries BCE). We discuss how the interplay between socio-political and environmental forces may have shaped the agency of subaltern social groups on the move, and the outcomes of this process. Ultimately, this analysis can contribute towards a framework for the archaeological study of marginality and mobility/displacement-while addressing potential limitations in evidence and methods.
\end{abstract}

Keywords: Marginality; climate change; environment; ancient Italy; resilience; archaeology; survey evidence; displacement; mobility

\section{Introduction: Approaching the Agency of the Displaced, Then and Now}

The Catalyst papers suggested for this chapter by the Editors (Ribeiro et al. 2017, this volume; Nobre and Nakano 2017, this volume) go to the core of our research interest, namely: the agency of marginalized social groups, and the writing of alternative histories where non-élite agency is the guiding thread (see Perego and Scopacasa 2016a). Both Catalyst papers concern communities of marginalized people in modern-day Brazil, who settle in areas from which they constantly risk being evicted. Urban shantytowns developed in Brazil over the second half of the twentieth century, largely owing to the influx of migrants from rural areas where living conditions were poor and job opportunities scarce. These migrants were drawn to big cities in search of a better life, but had serious difficulty integrating once they arrived. Whilst the migrations have waned in recent years, shantytowns have persisted for various complex reasons, which include demographic growth, social inequality, the urban property market, and drug trafficking (see Perlman 2010 for a balanced assessment). Yet, what strikes us about the Catalyst pieces is how much the marginalized actively shape their own lives, rather than merely suffering the consequences of what the powerful choose to do. The Dandara community, for example, are not at the mercy of big business or the state; on the contrary, they make their own decisions, such as which space to claim for themselves; how their settlement should be built and how their community should be run (Ribeiro et al. 2017, this volume). They even appear to have 
altered the spectrum of what was possible within the bounds of the law: in April 2017, they legalized their settlement, by turning their (originally) illegal occupation of private property into legal ownership through state intervention.

However, the Catalyst cases-and the Dandara piece in particular-also draw attention to the fact that agency is about more than human volition-be it the volition of the powerful or that of the marginalized. The Dandara people moved into an environment that presents serious challenges. Although the settlement is within the city of Belo Horizonte (one of the largest in Brazil), it was originally built on land devoid of basic urban infrastructure such as sanitation, running water, sewage, power and gas lines. Additionally, it sits on a steep hill where the terrain is muddy and uneven; streets and alleys are unpaved and prone to landslides-especially during the summer months of torrential rainfall that characterize the subtropical humid climate of south-eastern Brazil. These are common problems facing Brazilian shantytowns in general, which tend to be far less organized than the Dandara settlement (see Nobre and Nakano 2017, this volume). Like Dandara, shantytowns tend to develop in areas that are beset with environmental hazards, such as pollution and risk of landslides and/or flooding (Rosa Filho 2012; see also Bras et al. 2016 on Haiti). These environmental constraints seem to have a bearing on the trajectory of marginal social groups, who usually lack the means to deal with environmental challenges as effectively as they might do, if they had modern technology and urban planning on their side.

Human agents operate within existing social structures that both enable and constrain their actions (Bourdieu 1977; Giddens 1984; Dobres and Robb 2000; Dornan 2002; Gardner 2004; Robb 2007, 2010; Perego 2011; Perego and Scopacasa 2016b). Environmental factors also play a role in shaping the possibilities and limits of human agency (Crosby 1986; Barad 2007; Latour 2007). In a way, non-human elements-such as soil, terrain, climate, vegetation and fauna-also possess agency, in the sense that they can also contribute to the shaping and transformation of reality. These are forces that interfere in the rate and direction of social change-not in an absolute or deterministic way, but as factors that operate alongside human agency. By factoring in non-human as well as human agents into the narrative, it may be possible to reach a deeper understanding of social change. This involves approaching the environment not as a mute backdrop to social relations and conflicts, but as an active and intrusive force (among others) in processes of migration, mobility and displacement.

Ultimately, the Catalyst papers for this chapter raise a set of fundamental questions: how, and in what circumstances, can human agency rework the negative effects of social and environmental constraints, and channel them towards unexpected ends? How can we address these issues in the past? What are the interpretative challenges posed by "imperfect" archaeological data? It is with these questions in mind that we turn to our ancient case-study of (potential) displacement in Republican-period Italy, as a counterpoint narrative that allows us to visualize patterns from a long-term perspective, in a context that seems to bear some resemblance to the Dandara experience.

We argue that, during the late fourth/third centuries BCE, drought-prone areas of southern Italy were occupied by incomers of possible non-élite status. This is indicated by survey and excavation evidence of the spread of small rural sites around the ancient city of Canusium and nearby Cannae in Daunia. These developments have been interpreted as demographic growth and/or agricultural expansion. In this paper, we hypothesize that the spread of small rural sites may indicate non-élite people's response to rising inequality and instability, by making the most of relatively poorer agricultural land, as well as their resilience to environmental challenges. We begin by arguing that the inhabitants of the small rural sites may have included people of potentially non-élite status. We then discuss how the infilled areas may have presented challenges to agriculture, such as thin soil layers and more difficult access to water (being further away from the well-watered Ofanto valley and urban centre of Canusium). Furthermore, climate data suggests that the infilling happened during a warming phase, which may have aggravated the challenges posed by the arid-prone areas occupied (although the timing and impact of this warming trend remain to be fully assessed). Lastly, the written sources show that these communities found themselves at the centre of major turning-points in history, 
such as the Hannibalic War and the decisive battle fought near Cannae in 216 BCE. By putting the available evidence together, we aim to contribute towards a discussion of: (i) how socio-political and environmental forces may have shaped the agency of subaltern groups in the past; (ii) the relationship between environmental and socio-political developments in the Roman world. We also discuss the limitations and problems in the evidence and methods, defining directions for future research.

\section{Republican-Period Daunia, c.325-150 BCE}

The region of Daunia in ancient Italy (Figure 1) affords an interesting case-study on potential marginalization and displacement in the distant past. Recent archaeological surveys have produced a general picture of settlement patterns during the last six centuries BCE (for the latest results, see for example Goffredo 2006, 2010, 2011; Goffredo and Volpe 2006; Volpe et al. 2015; see also Compatangelo Soussignan 1999). Historical narratives shed some light on the socio-politica organization of Daunian communities and their relationship with Rome (below). Lastly, there is sufficient scientific data to estimate certain environmental conditions that may have been present in the region during the time of the Roman expansion in Italy (late fourth-second centuries BCE) - although the chronological resolution of the environmental data is relatively low, as we shall see.

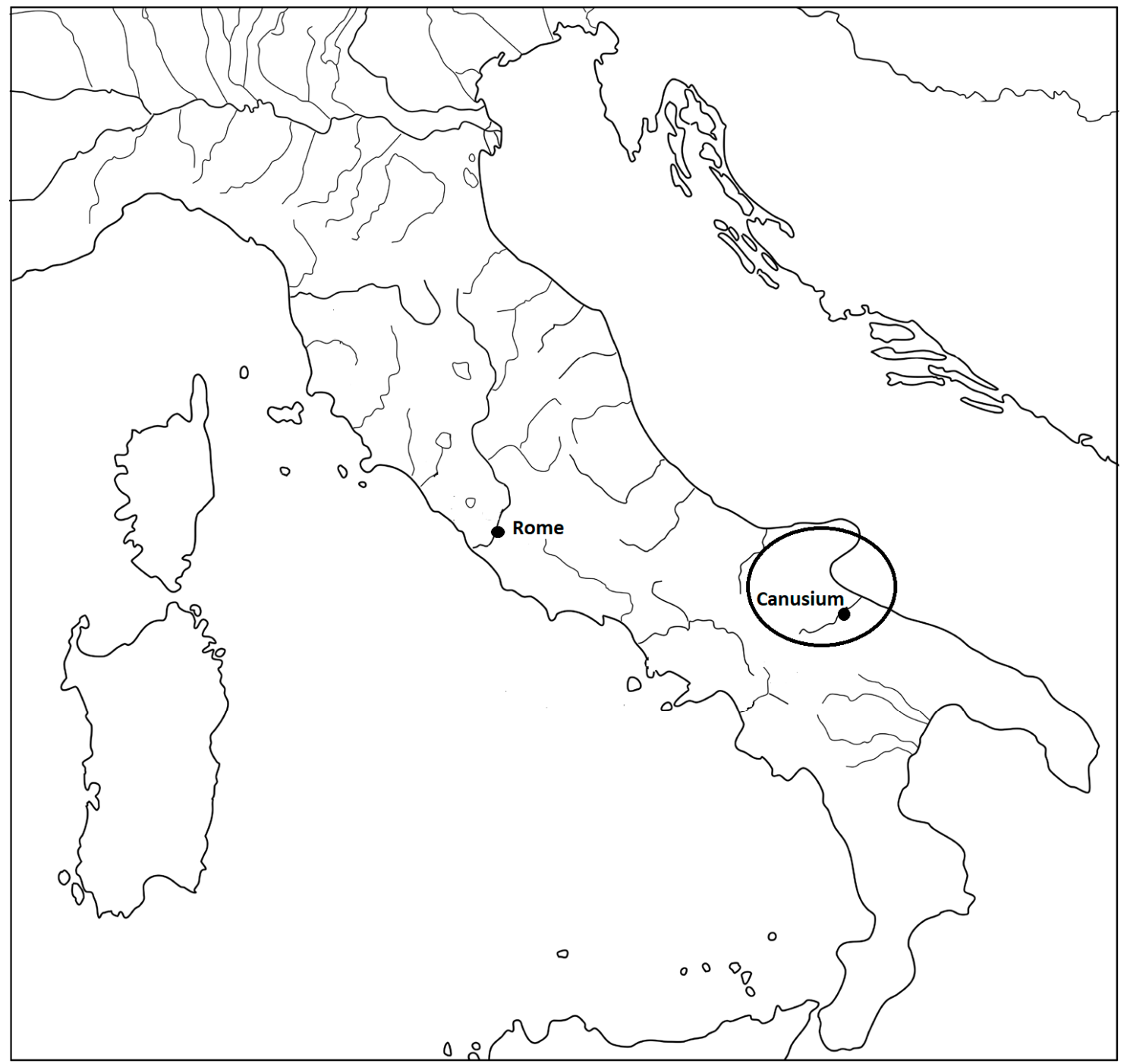

Figure 1. Daunia in Italy (courtesy of C. Iaia, modified by R. Scopacasa with permission). 
In the fourth century BCE, just before Roman encroachment began, the Daunian landscape was dotted with nucleated centres on average $20 \mathrm{~km}$ apart (Volpe 1990; see Volpe et al. 2015 on the nature of urbanism in the region). One of the major cities was Canusium in the Ofanto valley: its development as a nucleated centre began in the seventh century $\mathrm{BCE}$, but it is only in the late fifth-fourth centuries that urbanization seems to take off (Volpe 1990, pp. 36-40; Goffredo 2010, p. 15). According to Livy, Canusium was one of the main cities in Daunia alongside Arpi and Teanum: these three cities probably competed for regional hegemony (Fronda 2006, p. 416). In 326 BCE Arpi made an alliance with Rome, most likely as a strategy to defeat Canusium and Teanum, which were conquered in 318-7 BCE (Livy 9.20.4-8; Diod. Sic. 19.10.2). From then on Canusium was probably a Roman ally, apparently retaining much of its autonomy as no colonies seem to have been founded in its territory, nor do we hear of any of its lands being confiscated (Volpe 1990, p. 50). ${ }^{1}$ Nevertheless, Roman hegemony probably had some impact on local society, possibly creating new levels of inequality: certain pro-Roman families may have been favoured (see below). That some people in Canusium thrived in the context of the Roman alliance is suggested by material evidence of prosperity from the third century, such as the opulent chamber tombs or hypogea with south Italian amphorae (e.g., the "Barbarossa hypogeum": Volpe 1990, p. 226). The overall image of a prosperous and confident community is reinforced by evidence that the city was minting its own coins and conducting its own foreign policy (Fronda 2006, p. 409, n. 51). On the eve of the Hannibalic war (218 BCE) the city most likely boasted stone fortifications (Livy 22.52.7, 22.54.6; Fronda 2006, p. 410). Many of the neighbouring centres (including Arpi) defected to Hannibal in 216 BCE after the crushing Roman defeat at Cannae. Canusium, however, remained loyal to Rome, suggesting that the pro-Roman element in the city was powerful. The Carthaginians retaliated by ravaging Canusium's fields (Fronda 2010, p. 55). Whatever the impact of these devastations (see the discussion in Goffredo 2008, 2010, 2011), it seems that by the early first century CE Canusium had regained some of its economic standing: Strabo (6.3.9) mentions a thriving emporium on the Ofanto River banks, while Pliny the Elder (8.190) notes Canusium's eminence in wool production and trade.

\section{Approaching Displacement and Mobility: The Archaeological Evidence}

Survey and excavation evidence suggests a marked increase in small rural sites around Canusium at the time of the Roman conquest. This trend has been interpreted as evidence of demographic growth and/or agricultural expansion. An assessment of the data available suggests that the rural site boom may have happened in a context of social inequality, with people of potentially non-élite status settling further away from the urban centre and well-watered river valley.

In 2003-2004, archaeologists from the University of Foggia carried out intensive field-walking surveys of the territories around Canusium and Cannae-a smaller, most likely unfortified centre or vicus further down the Ofanto valley, which may have been controlled by Canusium, and the site of the major battle between Rome and Carthage in 216 BCE. Among the many important results of the Ofanto survey was the discovery of a sharp increase in the number of rural sites around Canusium and Cannae in the late fourth-third centuries BCE (Goffredo 2010, p. 20). A total of 119 sites most likely dating c.325-200 BCE were identified in the survey area (Figures 2 and 3). ${ }^{2}$ According to Goffredo (2011, p. 103, n. 61), 62 of these 119 sites are securely dated to the late fourth and third centuries, while the remaining 57 sites probably date from the same period. Most sites were characterized by the survey team as rural houses (case) or "small farms" (fattorie) in view of their size and the surface finds; these generally consist of building materials (large tufo or limestone blocks, cut stone, plaster, brick, tile, and occasionally marble slabs), tools (loom weights and artefacts identified as millstones) and pottery

\footnotetext{
See also (Scopacasa 2016) on the Roman expansion in Italy and (Goffredo 2011) on Canusium specifically. Goffredo (2008, p. 288; 2010, pp. 20-21; 2011, pp. 102-3).
} 
fragments, covering areas of around 300-1000 sq m. ${ }^{3}$ The conspicuous presence of tableware among the surface pottery suggests these sites were more or less permanently settled (below). ${ }^{4}$ Of the sites in use during the late fourth-third centuries $\mathrm{BCE}$, only 33 seem to have been in use in the preceding period (c.600-325 BCE: Figure 2). ${ }^{5}$ Most of the late-fourth and third century sites apparently continued to be frequented into the second century and later, as indicated by datable pottery finds such as later black gloss, grey and sigillata wares (Figure 4$){ }^{6}$

Therefore, the number of known rural sites in the Canusium/Cannae countryside seems to nearly quadruple after c.325 BCE-or double, if we consider only the 62 sites that can be securely dated c.325-200 BCE (according to Goffredo 2011, p. 103, n. 61). Many of the new sites, as noted above, apparently remained in use throughout the third and second centuries $\mathrm{BCE}$, and some survived, or were re-occupied, into the late Republican and Imperial ages, with the "houses" becoming larger and more complex in terms of number of rooms and internal spatial organization (Goffredo 2008). As such, the infilling of the Canusine countryside is similar to contemporaneous developments elsewhere in Italy, including the Biferno valley in Molise (Lloyd 1995), the Sangro valley in Abruzzo (Lloyd et al. 1997) and elsewhere in Italy and the central Mediterranean (Terrenato 2007). In all of these regions, small rural sites multiply from the late fourth century onwards. These developments constitute an overall trend towards the infilling of the countryside, spurred by demographic growth and the intensification of agriculture (Terrenato 2007; Goffredo 2011, p. 108 on Canusium; Goffredo and Ficco 2009, p. 38).

This familiar picture of the infilling of the Italian countryside is not normally approached as evidence for mobility or displacement. However, as regards our Daunian case, there are still some key questions that remain to be addressed more fully, such as who the incomers were, where they came from, what compelled them to move into these areas, and why some areas seem to have attracted more incomers than others. In this respect, the Catalyst papers offer an alternative framework for approaching the ancient evidence: they remind us that the infilling of land can be a complex issue connected with displacement, social inequality, ownership rights, environmental hazards and human agency (see also Terrenato 2007, pp. 18-19, for a discussion of such issues). The Dandara settlement in modern-day Brazil, for example, is evidence of community growth and land infilling, as well as aggravated social inequality. One way to approach these questions is by carefully charting the trajectory of specific communities and the different agents at work. By focusing on the micro-level, we may gain new insights that can contribute towards the overarching model.

3 (Goffredo 2008, p. 288; 2011, pp. 102-3). For the definition of "fattoria" and "casa" regarding the evidence under discussion, see (Goffredo 2011, pp. 68-69); "small farm" is used in (Goffredo 2010, p. 20); until the full dataset is published, we will employ the term "small rural site" as a general category.

4 For the period under study, the pottery evidence consists mostly of black gloss; Gnathian and Apulian wares to a lesser extent: see (Goffredo 2011, pp. 209-305).

5 Not all of these sites are shown individually in Figure 3; see (Goffredo 2011, pp. 102-3).

$675 \%$ of the sites around Canusium appear to have remained in use; the greater disruption around Cannae may be connected with the devastating battle of 216 BCE: (Goffredo 2008; 2010, pp. 23-25); see also below. 

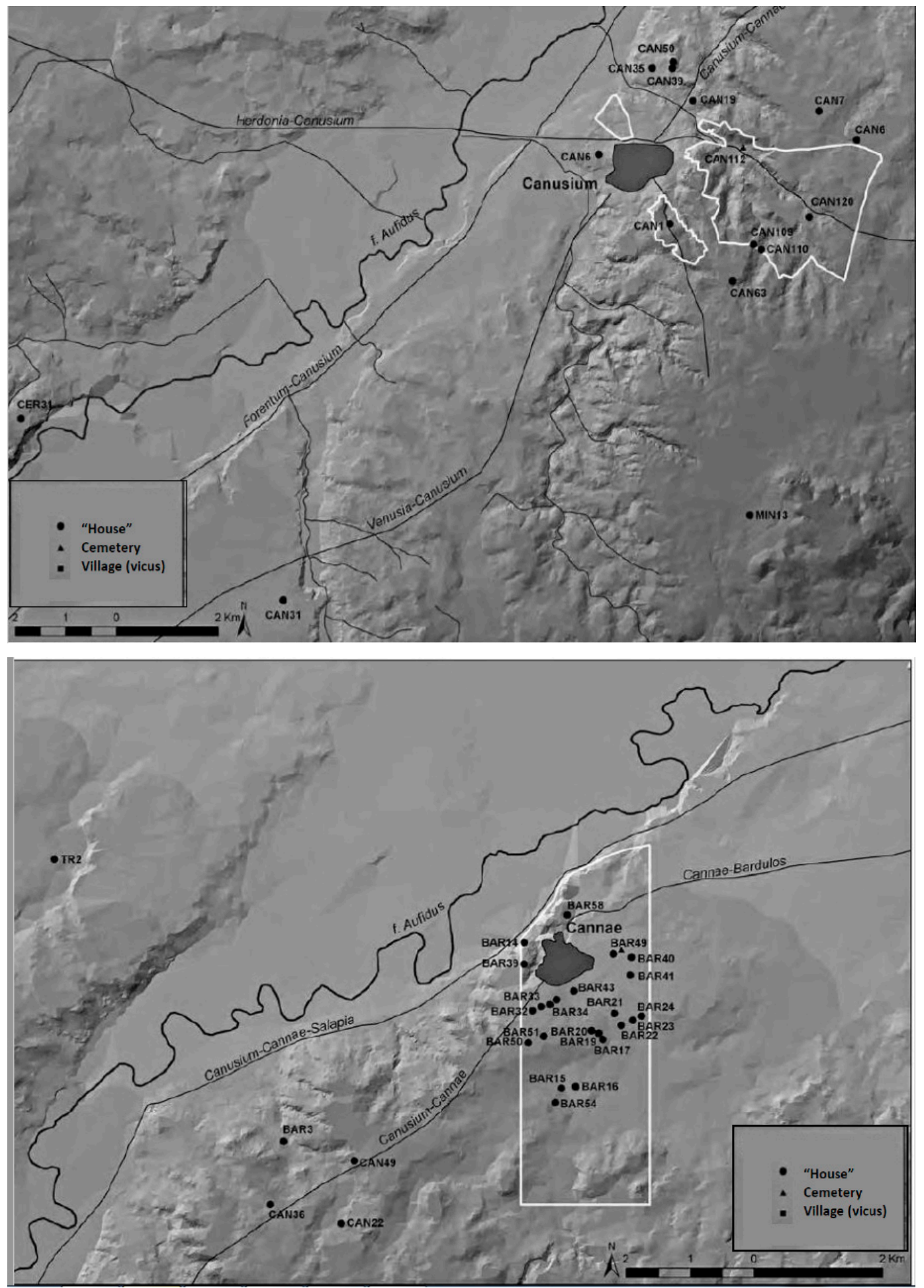

Figure 2. Sites around Canusium (top) and Cannae (bottom) identified in the Ofanto survey, sixth-late fourth centuries BCE (adapted from Goffredo 2010 with permission). 

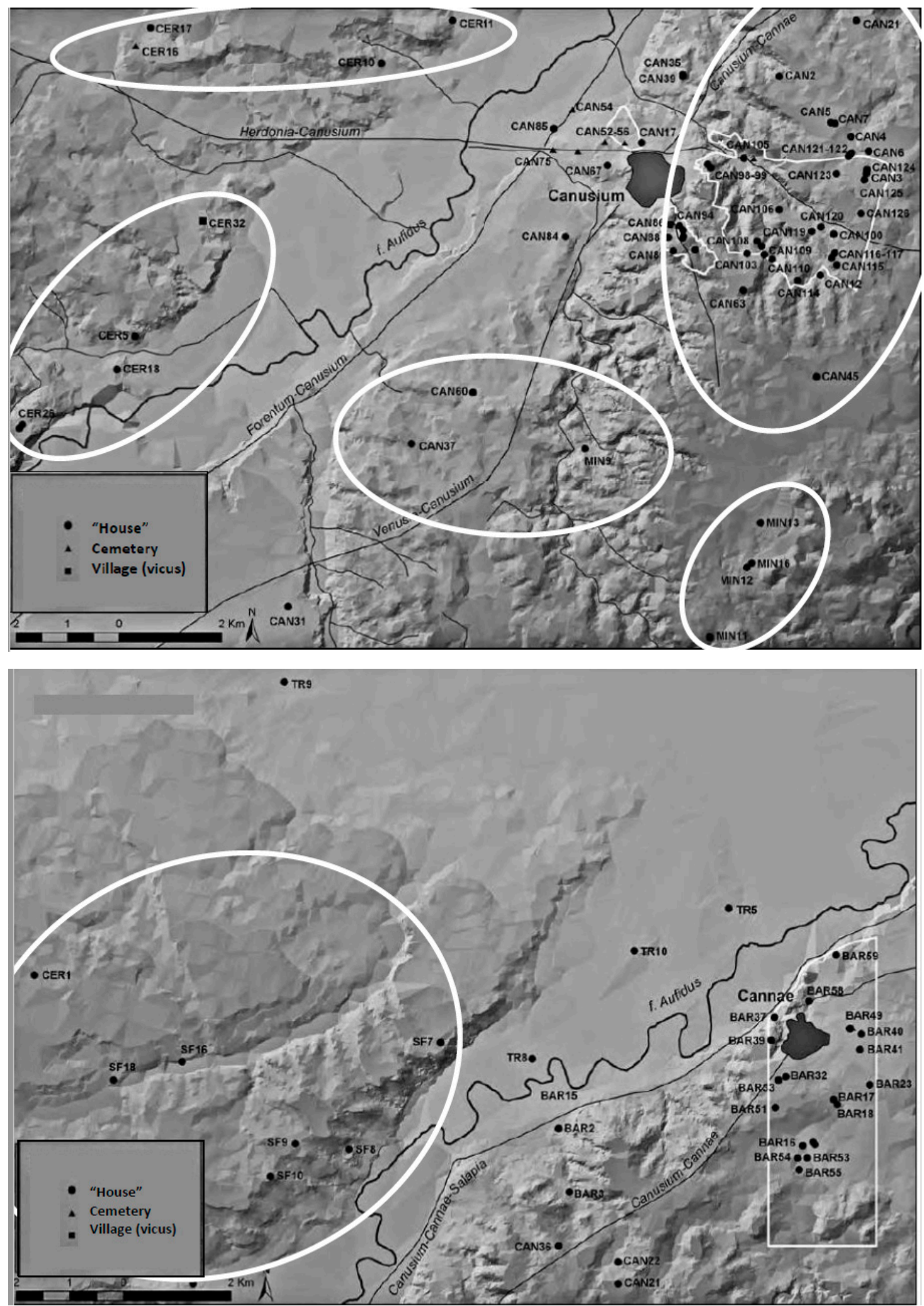

Figure 3. Sites around Canusium (top) and Cannae (bottom) identified in the Ofanto survey, late fourth-third centuries BCE; circles indicate new sites in the Tavoliere (northwest) and Murge (southeast; adapted from Goffredo 2010 with permission). 

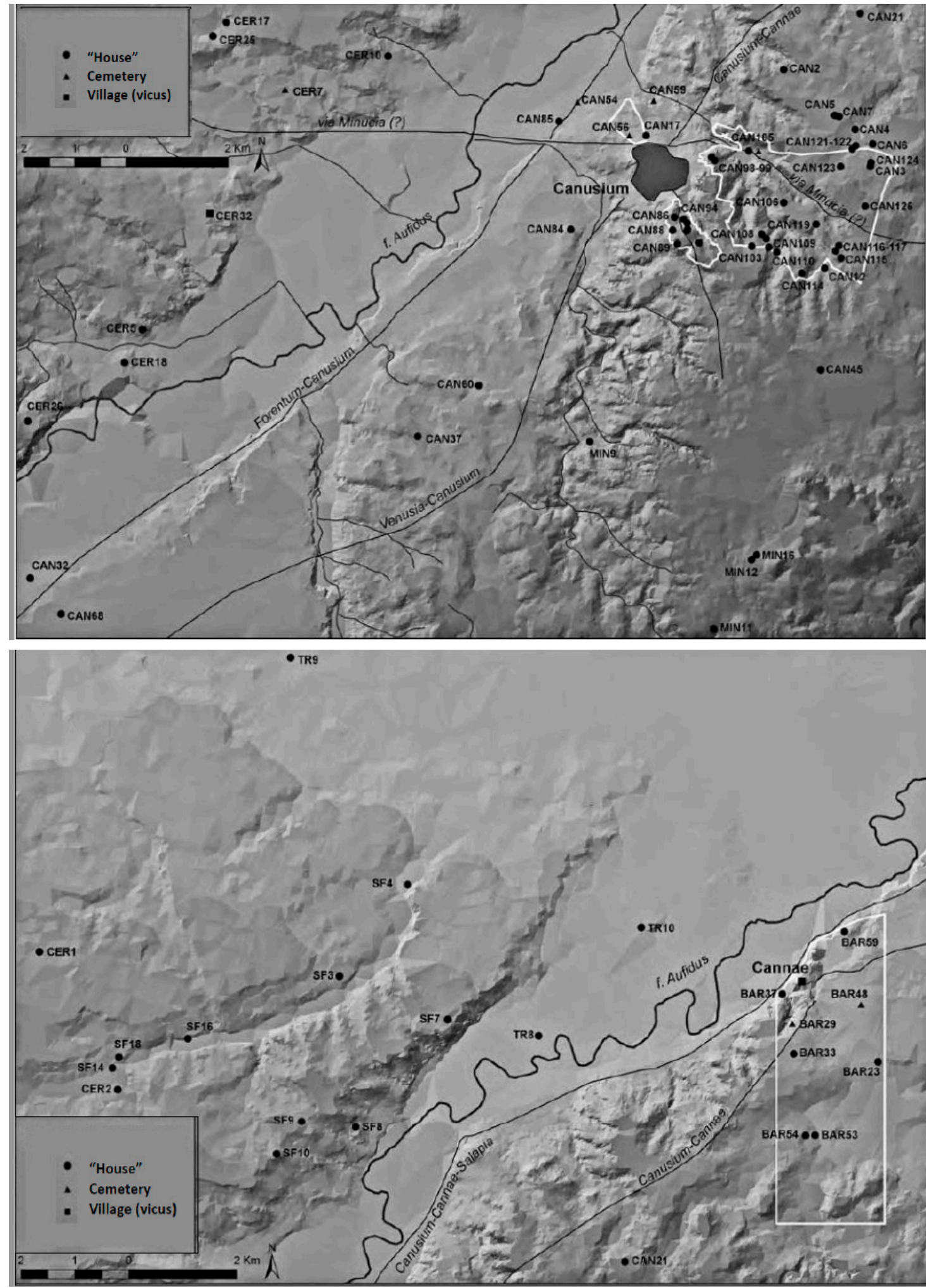

Figure 4. Sites around Canusium (top) and Cannae (bottom) identified in the Ofanto survey, second-first centuries BCE (adapted from Goffredo 2010 with permission).

The people that moved into the Canusine countryside are anonymous social agents, unmentioned in the historical record. Yet, a combined analysis of the historical and archaeological records may provide some initial clues as to the social dynamics behind the increase in rural sites, although we 
must stress the preliminary character of the survey evidence available. First, the nature and function of the new rural sites are not completely clear, and more excavation is needed. However, the noticeable presence of tableware in all of the rural sites, such as black gloss and occasionally other pottery types such as Gnathian pottery, suggests that these sites were settled in the late fourth and third centuries BCE. ${ }^{7}$ Also consistent with settled communities is the presence of a small grave cluster among the rural sites. ${ }^{8}$ More importantly, a stone-built house from the late fourth century BCE (with a tomb in the courtyard) was excavated at Madonna di Costantinopoli just east of Canusium (site CAN67, Figure 3 top; Corrente 1997; Goffredo 2008; 2010, pp. 20-21). It is also significant that most of the rural sites under consideration feature building materials (e.g., cut stone, tile, brick, plaster, and occasionally marble and paving) and/or farming-related artefacts (millstones, dolia and loom weights; the latter would indicate the presence of looms, which might further point to stable occupation). This material is of uncertain date, and some of it could be from later periods, since many of the sites remain in use after the third century BCE. This would mean that patterns in the distribution of these objects could reflect a mix of periods (see also below). However, building materials which characterized the Madonna di Costantinopoli rural house (e.g., accurately squared tufo blocks and roof tiles) also appear in many other surveyed sites dated to c.325-200 BCE. ${ }^{9}$

Overall, the available evidence seems to suggest that the small rural sites around Canusium and Cannae in the late fourth/third centuries may have included small farmsteads-although more data is needed to further confirm and refine this picture. The existence of rural houses or small farms elsewhere in the Canusine countryside and nearby areas has also been argued based on aerial photography and/or earlier survey work. For example, squarish and rectangular structures interpreted as small farmsteads have been identified at sites such as Ripalta, Pozzo Monachiello, Fontana del Bue and San Lorenzo (Compatangelo Soussignan 1999, pp. 111-13; Goffredo 2006, pp. 542-43; 2011, p. 213; Goffredo and Volpe 2006). While survey evidence (pottery, tiles, building materials) has afforded a preliminary dating of some of these contexts to the Republican period (e.g., Ripalta), further data are needed for a full chronological assessment of these sites. The size and multi-room organization of some of these structures may suggest a dating later than the fourth century BCE—or that relatively complex rural structures already existed in the area c.325-200 BCE. ${ }^{10}$

The apparent lack of imported or intrusive artefacts (Goffredo 2010, p. 20; 2011, pp. 209-305) could indicate that the people who frequented the rural sites were (mainly) local. Yet, material culture is a difficult basis for assessing cultural and/or ethnic identity, since "pots do not equal people" (Jones 1997; Scopacasa 2015 on ancient central/southern Italy). Also, only a few of the small rural sites have been excavated and studied in detail. We should not rule out the possibility that migrants were among the incomers to the Canusine countryside, given the historical evidence for mass migration in third- and second-century BCE Italy (see Isayev 2017). To take one example, in 177 BCE, 4000 Samnite and Paelignian families are said to have moved to the Latin colony at Fregellae (Livy 41.8.8; Isayev 2017, pp. 40, 44). Earlier in 199 BCE, the colonists in Narnia (Umbria) complained to the Roman senate that people of a different status (non sui generis) were entering the colony and passing themselves off as settlers (Livy 32.2.6). We also read about forced migration, such as the Roman deportation of 40,000 Ligurian families to southern Italy in 180-178 BCE (Livy 40.38.6). ${ }^{11}$

7 (Goffredo 2008; 2011, p. 103), and the preliminary finds catalogue at 209-305 (Volpe et al. 2015).

8 These consist of five tombs from the late fourth/third centuries BCE: site CER16, Figure 3 top; (Goffredo 2011, p. 211).

9 (Goffredo 2008, pp. 288-89). The use of tufo blocks as building material in house foundations is attested in Canusium and its countryside since the late 6th century BCE (Goffredo 2008, p. 289). Artefacts pointing to stable inhabitation such as loom weights also appear in sites that seems to lack evidence dating later than the late fourth-third centuries BCE (according to Goffredo 2011; e.g., BAR49) although the challenges posed by survey data must be taken into account in this regard.

10 For example, the Ripalta building identified via aerial photography is $63 \times 63 \mathrm{~m}$ and probably featured a portico; the surface finds also indicate a phase of use dating to late Antiquity-an enlargement of the original building might date to this later phase (Goffredo and Volpe 2006, p. 229; Goffredo 2011, pp. 300-1).

11 There are also numerous instances of human mobility resulting from Roman colonization schemes in Italy and overseas: see (Isayev 2017, pp. 42-46) for an in-depth discussion. 
However, if migrants were among the newcomers to the Canusine countryside, they are currently indistinguishable in the archaeological record as we have it.

There is some indication that the rural infilling of the late fourth/third centuries took place in a context of high social inequality. By the Hannibalic war, Canusium was home to some exceptionally well-off families, such as that of the noblewoman Busa who reportedly fed, clothed and paid ten thousand Cannae survivors from the Roman ranks. ${ }^{12}$ These élites seem to have adopted the city as their main area of activity, given the high level of investment in urban development and display during the late-fourth/third centuries. ${ }^{13}$ These same élites probably derived their wealth from the exploitation of resources and labour in the local countryside, where the small rural sites were increasing in number. ${ }^{14}$ Although the élites were apparently interested in residing in the city, it is quite possible that they controlled nearby lands where infilling occurred (Volpe et al. 2015, p. 490). If that was the case, some of the small rural sites around Canusium and Cannae could have been occupied by tenant farmers and sharecroppers-although we should not rule out the possibility that smallholding peasants were also present (see Terrenato 2007, p. 19, on the reorganization of power relationships between rural subordinates and élites in fourth-third century BC Italy).

If the Canusine élites adopted the city as their primary place of residence, this may have limited the options available for commoners as to where they might set up residence (Goffredo 2010). Indeed, the fact that the infilled areas of the Canusine countryside seem to have been sparsely occupied for most of the first millennium BCE until the late fourth century, might indicate that they were not seen as particularly attractive-although it is possible that earlier sites were present but are now inconspicuous in the survey record. ${ }^{15}$ While few of the surveyed rural sites have been excavated, rural houses in the area might not have been as lavish as the élite urban structures-although not as precarious as the wattle-and-daub huts from earlier periods. A good example is the excavated house at Madonna di Costantinopoli, which was a one-room, stone-built house with simple layout, tiled roof, paved floors and an external beaten-earth courtyard (Goffredo 2010, pp. 15, 21). According to Goffredo, the building resembles contemporaneous rural houses elsewhere in Republican Italy. ${ }^{16}$ On the other hand, some rural dwellings may have continued to be made of perishable materials.

Viewed from the vantage point of the Catalyst papers, the evidence from Canusium and Cannae raises a key question: does the infilling of the Canusine countryside indicate rising levels of prosperity across the social transect, and the democratization of land ownership through the claiming of new farmland by peasants? Or does it reflect growing social inequality and exclusion, with increasingly wealthy élites pushing people away from the city and the river valley, towards more distant (and potentially more challenging) lands, which now needed to be exploited as a means of survival for lower social segments, and/or because of new tributary demands by the élites (who may have owned some/most the surrounding lands)? How can we differentiate further between rural sites that were settled as farmsteads, and others that were possibly frequented on a less stable basis? And how can an in-depth, micro-level analysis of the Canusine case contribute to our understanding of similar developments in other regions? As we discuss below, one way to begin addressing these questions is by factoring in the environmental context.

12 Livy 22.52.7; Val. Max. 4.8.2; see below for further discussion.

13 E.g., the lavish hypogea: (Volpe 1990); on the Canusine élites as city-oriented, see also (Goffredo 2010; Volpe et al. 2015).

14 (Goffredo 2010, pp. 29-30; Volpe et al. 2015, pp. 489-91); a more thorough assessment will be possible once more sites have been excavated.

15 Evidence from the Ofanto survey suggests a tendency for settlements to concentrate around the nucleated centre and the river valley (Figures 2 and 3). The start of urbanization might have influenced such a trend: see (Goffredo 2010); see below on the environmental characteristics of the infilled areas.

16 The comparisons mentioned (Monte Moltone-Tolve and Mancamasone-Banzi) range between 150-200 sq m: (Goffredo 2011, p. 105); he also notes that sites identified as "case" in the Ofanto survey may have ranged between 100-150 sq $\mathrm{m}$ in size: (Goffredo 2011, p. 69). As noted above, the occurrence of cut stone, tufo or limestone blocks, tiles and pottery in the late fourth/third-century rural sites suggests that similar houses may have been present elsewhere in the Canusine countryside (Goffredo 2010, p. 21). On Republican-period farmhouses in Italy see (Terrenato 2007). 


\section{The Environmental Context}

Like other social phenomena, mobility and displacement have an environmental dimension, and can be approached in terms of human-environment interaction. Recent studies have explored the role of climate and environmental changes in human mobility and migration (e.g., Black et al. 2011; Drake 2017). A similar approach is useful with regard to the late-fourth/third century infilling of the Canusine countryside, where incomers were occupying drought-prone areas that potentially presented challenges to agriculture (such as thin soil layers and more difficult access to water). Climate data suggests that this happened during a warming phase, although the intensity, timing and impact of this warming trend are still difficult to assess. In this section, we seek to place the infilling of the Canusine countryside in its environmental context by presenting a brief overview of some of the climate and environmental evidence available, while stressing the possibilities and problems of the data currently published.

The infilling of the countryside around Canusium and Cannae apparently involved arid-prone areas that are sensitive to climate shifts and might have been challenging to agriculture: the northern slopes of the Murge plateau, and the southern terrace of the Tavoliere plateau (Figure 3). ${ }^{17}$ The Tavoliere was originally a raised seabed composed of gravels and clays; it is one of the driest areas in the Italian peninsula with an average yearly rainfall of under $500 \mathrm{~mm}$, and is currently at high risk of desertification (Dipace and Baldassare 2005; Frattaruolo et al. 2008; Delano Smith 1996, p. 162). In summer the plateau becomes a suntrap, with temperatures occasionally rising over $40{ }^{\circ} \mathrm{C}$ (Small 1994, p. 544). Such propensity to extremes does not appear to be entirely the result of recent climate change: over the last ten thousand years the Tavoliere seems to have occasionally deteriorated into a dustbowl probably owing to variations in temperature and rainfall (Boenzi et al. 2002; Broodbank 2013, chp. 7; on rainfall unpredictability in modern-day Tavoliere: Delano Smith 1996, p. 162). There is evidence that such deterioration may have been happening to some extent in the third and second centuries BCE. ${ }^{18}$

On the other hand, the Murge is a karst limestone plateau where the soil layer can be relatively thin. While rainfall in recent decades has been moderate (with monthly rainfall averages ranging between 24 and $78 \mathrm{~mm}$ ), ${ }^{19}$ surface water is extremely scarce by current Italian standards-a feature that has affected agriculture in the Murge for centuries. ${ }^{20}$ A study of droughts in twentieth century Apulia suggested that the Murge and Tavoliere were the two areas where the underground water table was most sensitive to decreases in rainfall, since both areas displayed the greatest drops in the water table in times of drought (Polemio and Dragone 2004). Although it is not clear to what extent these findings also apply to the third and second centuries $\mathrm{BCE}$, the karst nature of the Murge may have made it a more challenging place for agriculture than the neighbouring Ofanto river valley. Any community seeking to settle in the Murge would have needed to reach the underground water table, which might have been contaminated to some degree by the infiltration of seawater, as seems to be the case nowadays. ${ }^{21}$

The Tavoliere and Murge have been breadbaskets in the past-for example, during the Middle Italian Neolithic (c. sixth millennium BCE: Whitehouse 2013) when the region was densely settled by farming communities (Skeates 2000; Whitehouse 2013). Similarly, in the Early Modern period (AD 1440-1530) the Tavoliere and Murge apparently yielded the largest quantities of grain in southern

17 (Goffredo 2010, p. 21); see below for a discussion of site location and inter-site distances.

18 See below, and Perego and Scopacasa in preparation, for a more fair-grained discussion of climate oscillation in late prehistoric Italy.

19 http://www.agrometeopuglia.it/opencms/opencms/Agrometeo/Climatologia/mappeClima (dataset covers the period 1951-2001).

20 (Small 1994, pp. 544-45); see (Snowden 1986) on the dramatic social effects of drought in Apulia in the early twentieth century.

21 (Polemio and Dragone 2004, p. 187); one exception is the relatively fertile area of the Murge known as the Fossa Bradanica, which is nonetheless c.50 km south of Canusium and is not included in the published results of the Ofanto survey: see (Small 1994). 
Italy. ${ }^{22}$ On the other hand, the Tavoliere in particular has also been vulnerable to desertification: over the last ten thousand years, the plateau seems to have shifted between a breadbasket and dustbowl depending on rainfall. An especially severe downturn seems to have happened in the Italian Late Neolithic, when a general drying of the Mediterranean climate seems to have coincided with an apparently drastic reduction in the number of farming villages in the Tavoliere. ${ }^{23}$

As regards our period of interest, the third and second centuries BCE roughly coincide with the start of the Roman Warm Period (RWP). This is recognized as a phase of warmer temperatures and possibly drier conditions in Italy and many parts of the Mediterranean and northern hemisphere. ${ }^{24}$ The climate data for third- and second-century BCE Italy is fragmentary and often ambiguous, largely because of the low chronological resolution of the available climate records. At the present state of knowledge, it is dangerous to generalize. Nevertheless, the onset of the RWP has been identified in a number of proxy (approximate) climate records (see Manning 2013, pp. 134-35 with bibliography), including the GISP2 ice cores from Greenland (Finné et al. 2011, pp. 1867-68), lake level oscillations in central Italy (Giraudi 2014, pp. 941-42), marine sediment cores from the Adriatic (Piva et al. 2008), stalagmite records from northern Italy (Frisia et al. 2005, p. 451; Finné et al. 2011, pp. 3164, 3168), and Alpine glacier retreats (Holzhauser et al. 2005). Some specialists argue that temperatures in Italy during the RWP may not have been too different from those of recent decades (Giraudi 2014, pp. 941-42; see Sallares 2007, pp. 19-20 on other Mediterranean regions). If accurate, this could mean that the Tavoliere might have been facing a desertification threat to some degree in the third and second centuries BCE, as it has been in recent decades. ${ }^{25}$

While arable farming would still have been possible in the Tavoliere, farmers wishing to settle there in the third and second centuries BCE may have had to rely on a fine margin of climatic stability. Similarly, the karst plateau of the Murge, with its thin soils, may have exacerbated the effects of warmer temperatures and potentially unpredictable rainfall. Therefore, the onset of the RWP potentially made the area more vulnerable to variations in rainfall, as has been the case in recent decades (e.g., Polemio and Dragone 2004; above). The climate data seem to cohere with literary testimony suggesting that arid conditions prevailed in Apulia by the first century BCE (Horace's 'parched Apulia': Epod. 3.16; see also: Carm. 3.30.10-12). Yet, it was apparently in the context of the early RWP that both these drought-sensitive plateaus seem to have been occupied by small rural sites, which may have included farmsteads.

\section{Occupying Marginal Landscapes?}

The foregoing discussion suggests that the incomers to the Canusine countryside (Tavoliere and Murge) in the late-fourth and third centuries BCE included people of potentially non-élite status settling in drought-prone areas that might have presented challenges to agriculture (although, as noted above, much of the environmental evidence available is still difficult to interpret). In this section, we suggest the hypothesis that the spread of small rural sites around Canusium may indicate non-élite people's response to rising inequality to some extent, as well as their resilience to environmental

22 (Sakellariou 2011, pp. 232-33); it may be significant that this happened at the start of the Little Ice Age, a period of unusually cold/wet conditions in Europe: (Grove 2001).

23 (Boenzi et al. 2002; Broodbank 2013); but see (Whitehouse 2013, pp. 72-73) for a critical discussion of the evidence and dating; she argues that the decrease in villages may have been caused by soil over-exploitation alongside climate change.

24 (Lamb 1995, pp. 156-59; Sallares 2007, pp. 19-20; McCormick et al. 2012, pp. 174-75; Manning 2013, pp. 134-35). Both De Ligt (2012, pp. 27-30) and Isayev (2017, pp. 24-25, 183-84) envisage a potential one degree Celsius temperature rise in Italy c.300 BCE.

25 But see (Harris 2013, p. 2), on how the RWP warming may have varied in intensity depending on the region: he notes that Pliny's description of his villa in Tifernum suggests a colder climate than currently; for further discussion of this point, see Perego and Scopacasa in preparation. 
challenges-by making the most of relatively poorer agricultural land. ${ }^{26}$ A preliminary examination of surface finds suggests that farming and textile production (possibly connected with sheep rearing) may have been important activities in the small rural sites, although this material is very fragmentary and difficult to date.

The rural infilling around Canusium and Cannae may have been connected with historical processes affecting the region, such as the Roman conquest of the late fourth century. Although one must avoid being Romano-centric in discussing evidence for social change in Republican Italy, Roman encroachment after 320 BCE probably had a bearing on local social dynamics in Canusium. ${ }^{27}$ Families that were favourable to Rome may have received special treatment. ${ }^{28}$ One potentially revealing example is that of the Canusine noblewoman Busa, who allegedly took in the Roman survivors of the battle of Cannae (216 BCE) and gave them food, clothing and money for their trip home. ${ }^{29}$ Wealthy pro-Roman families such as Busa's may have thrived more than other Canusines who were less favourably positioned in the new power networks: these worse-off people may have been subjected to new forms of exploitation in the hands of the Roman-backed élites.

From this perspective, it is not implausible that the incomers to the Tavoliere and Murge may have included non-élite families that were compelled to move into, and remain, in lands that might have been regarded by the community as sub-prime. Seen from this angle, the increase in rural sites may to some extent indicate the movement of people away from the city and the well-watered river valley, perhaps to make way for larger estates. ${ }^{30}$ Alternatively, people may have moved into the Tavoliere and Murge because they were motivated (or forced) to exploit a wider range of the local ecosystem. They may have done this to satisfy growing surplus demands (e.g., wine, meat and dairy products) from the urban élites, who may have experienced a boost in authority because they were now supported by a hegemonic power.

If the small rural sites were in lands belonging to an urban-based élite, the people who apparently lived in them would still have had to eke out a living. Patterns concerning the location of the rural sites, and the nature of the surface finds, might shed further light on the social dynamics at work, while also stressing some of the difficulties of the survey data available. The known late-fourth and third century sites closer to Canusium and Cannae tend to be situated closer together (on average $500 \mathrm{~m} / 1 \mathrm{~km}$ apart), whereas contemporaneous sites further away from the centres are more spread out (on average $2-3 \mathrm{~km}$ apart: Figure 3). The greater distances between the remote sites might indicate the maintenance of larger lots, possibly to increase yields or to focus on animal husbandry in relatively poor land. To be sure, many of the Tavoliere sites are located on the edge of the plateau overlooking the river valley (Figures 3 and 4): this raises the possibility that people were building their houses on the plateau while farming the valley. However, the occurrence of sites further away from the edge (Figures 3 and 4) would suggest that some settlers were exploiting the poorer plateau land primarily.

As regards the surface finds, artefacts identified as millstones, loom weights and/or spindle whorls (Goffredo 2011) occur in sites closer to Canusium and Cannae, ${ }^{31}$ as well as in those located

26 There are interesting modern parallels where incoming populations (refugees) are given poorer agricultural lands as part of state-led initiatives such the 'Self-Reliance Scheme' in twentieth-century Uganda (Betts and Collier 2017, pp. 145-55; E. Isayev pers. comm.). The potential of such comparisons for the study of mobility in pre-Roman Italy warrants further study.

27 See (Woolf 2014) on the Romanization debate.

28 See (Bispham 2007, pp. 53-55) on Roman support for local aristocracies against possible popular uprisings in the central-Italian Volsinii and Falerii in the mid-third century BCE.

29 Livy 22.52.7; Valerius Maximus 4.8.2 notes that Busa managed to feed ten thousand Romans without damaging her fortune. But see (Fronda 2010, pp. 95-96) for a more nuanced assessment of the Busa episode: he notes that, according to Livy, the Roman survivors of Cannae were welcomed more warmly in Venusia than in Canusium; he argues that Livy's emphasis on Busa's generosity specifically, might indicate some unwillingness among other Canusine nobles to welcome the Roman soldiers as heartily.

30 As noted above, (Volpe et al. 2015, pp. 491-92) argue that the peasant households around Canusium were probably dependent on the urban aristocracies.

31 E.g., CAN6, CAN84-86 (Figure 3, top); BAR32-33, BAR37, BAR58-59 (Figure 3, bottom). 
further away (c. $2 \mathrm{~km}$ or more).$^{32}$ Bearing in mind the challenges posed by survey data, these patterns might suggest that farming and textile production (possibly connected with sheep rearing) were activities present in the small rural sites-including the more remote sites on the Tavoliere and Murge. One difficulty is that many of the survey sites remain in use after the third century BCE. In view of the preliminary data published to date, we cannot be certain that the farming-related artefacts in question date from the late fourth to third centuries. That millstones and loom weights may have been in use in the survey area during the late fourth and third centuries BCE is suggested by sites such as SF7, SF10, BAR32 and BAR49 (Figure 3, bottom). All of these seem to have been occupied during that period mainly, judging from the diagnostic pottery. ${ }^{33}$ However, the uncertain chronology means that the patterns in object distribution may refer to the second-first centuries BCE or later.

Regarding the pottery, black gloss is widespread in the small rural sites under discussion: this may point to common consumption practices that were shared by the people who occupied these sites. The preliminary data available, however, do not allow further insights into social differentiation or status. To approach black gloss as an indicator of social status, an analysis of the incidence of the different types in a single assemblage/context would be essential. The overall regional and supra-regional context of black gloss use-as well as provenance-should also be considered in depth (Amicone and Heinze, pers. comm.; see also e.g., Amicone 2015).

Whatever the factors behind the infilling of the Tavoliere and Murge, it may be significant that the onset of the RWP (around third-second centuries BCE) does not seem to have discouraged people from frequenting these arid-prone areas. Rather, we might hypothesize that the RWP constituted an added factor in local communities' development of strategies to exploit the (potentially) agriculturally marginal lands they occupied - either willingly or not. In particular, the evidence around Cannae would seem to suggest that sites on the Tavoliere fared better than those closer to the valley and town, which seem to disappear after the late third century, probably in connection with the devastating battle fought there in 216 BCE (Figure 4, bottom). Resilience against the ravages of warfare was possibly strongest among the more remote rural communities: it is notable in this regard that we do not seem to have evidence for the re-emergence of sites around Cannae after the Hannibalic war.

If our assessment of the environmental context of the Tavoliere and Murge is accurate, the preliminary historical, archaeological and environmental data may suggest a scenario where ordinary people might have borne the brunt of socio-political as well as environmental changes. The resilience of the small rural sites in these areas (suggested by the fact that many of them survived into the first century BCE or later) probably depended on the development of innovative coping strategies. Potentially, such strategies involved the kind of risk-buffered farming that Halstead postulates for Neolithic Thessaly (Halstead 1989, pp. 74-78; 2008), where peasant households resort to new forms of cooperation, including the suppression of hostility, as a means of coping with hazards to agriculture. In the Ofanto valley, preference might have been given to the cultivation of crops that survived well in warm and relatively dry conditions such as olives and vines. There is literary evidence for both vine and olive cultivation around Canusium in the first century BCE (Varro Rust. 1.8, 2.6.5; also Goffredo 2010, p. 25). This practice may already have been developing in the late fourth-second centuries. In addition, many of the Murge sites seem to have been situated in areas where access to the water table might have been easier (Goffredo 2010, p. 23). This suggests that the newcomers were selecting the best places in which to settle-which, in turn, raises the question of whether and to what extent there was competition for the best areas.

Although it is likely that the newcomers to the Tavoliere and Murge practiced arable farming, pastoralism may also have been important, both for subsistence and as a surplus-generating activity. Varro's account of long-distance transhumance between the Apennines and Daunia suggests that

2 E.g., CAN37, CAN60, MIN16, CER10-11, CER17, CER32 (Figure 3, top); SF7, SF10, TR10 (Figure 3, bottom).

33 See (Goffredo 2011, pp. 209-305); on the significance of the loom weights as indicators of stable occupation, see above. 
the Murge and Tavoliere may have supported pastoralism on a seasonal basis (Varro Rust. 2.1.16). Although Varro does not mention Canusium specifically, Pliny (NH 8.190) notes that the city's wealth was mainly derived from the wool trade. Both Varro and Pliny are later sources, and it has been argued that Varro's "big business" transhumance would have been feasible only from the first century BCE onwards. ${ }^{34}$ It is nonetheless possible that pastoralism was already significant in the late fourth, third and second centuries (see Whitehouse 2013, pp. 61-62; Robb 2007, pp. 146-47 on the Neolithic). Ultimately, the fact that the new sites may have been located in agriculturally marginal land does not necessarily mean that the incomers relied mainly on pastoralism. Pastoralism may have been a viable alternative to agriculture, especially in the sites further away from Canusium and Cannae, but it would not necessarily have been less risky or unpredictable. For example, late Medieval and Early Modern records suggest that herds in the Tavoliere were vulnerable to the severe climate (Delano Smith 1979, p. 246). Even if the newcomers of the late fourth-second centuries BCE practised pastoralism as an ecological strategy, we could still be looking at an instance where communities resorted to adaptable lifeways to exploit land that may have been considered sub-prime in previous centuries. This would have happened despite the unpredictability and/or potentially adverse impacts of prevailing environmental conditions (which remain to be assessed in more detail; further discussion of this issue is in Perego and Scopacasa in preparation).

\section{Concluding Remarks and Directions for Future Research}

We began this paper with a question inspired by the Catalyst articles: how, and in what circumstances can human agency rework the negative effects of social and environmental constraints, and channel them towards unexpected ends. We now present some preliminary conclusions, based on the foregoing discussion about the agency of non-élite and potentially marginalized social groups in the distant past. In doing so, we highlight some issues regarding the strengths and potential limitations of an integrated approach to socio-political and environmental change in the ancient world, and outline some possible opportunities for future research.

Our discussion has shown that an integrated micro-level approach to past displacementcombining historical, archaeological and environmental data-might contribute to our understanding of wider historical processes, such as the infilling of the countryside in Republican Italy. The occupation of the Tavoliere and Murge may have resulted primarily from socio-political changes in Canusium from the 320 s onwards. ${ }^{35}$ Social change may have been connected with the start of Rome's interference, and the possible emergence of a local pro-Roman élite who may have prospered at the expense of other Canusine social groups. Possibly, some people had no choice but to move into the Tavoliere and Murge. The possible scenarios are that: these incomers were driven out of more fertile or prime areas, such as the city itself or the well-watered valley; or they were compelled-or actively interested - to exploit a wider range of natural resources, to satisfy growing demands for surplus by the urban-based élites. In other words, the Canusine case raises the possibility that other instances of rural infilling in Republican Italy also involved issues of social inequality, power dynamics and environmental vulnerability-in addition to currently debated themes such as demographic growth, agricultural expansion and higher living standards. More micro-level analyses may contribute towards an overarching model of social change in this key period.

On a related point, our discussion of potential displacement and mobility in the Canusine countryside might add to our understanding of the relationship between environmental and socio-political developments in the Roman world. Recent approaches to human-environment

34 (Dench 1995, pp. 121-22); on pastoralism as more pervasive than grain cultivation in Imperial-period Apulia: (Small 1994, pp. 545-48); a key historical reference to transhumance routes or tratturi linking Daunia and the Apennine mountains dates to AD 1447: (Gabba and Pasquinucci 1979, p. 129; Dench 1995, p. 122).

35 But note that (Goffredo 2011) underlines continuity in view of some rural sites being already present in the sixth-late fourth centuries BCE. 
interaction in the Roman Empire have explored how the onset of environmental unpredictability impacted negatively on the economic and political functioning of the system, ultimately contributing to the collapse of Roman hegemony in the West (e.g., McCormick et al. 2012; McCormick 2013). Political and economic instability during the Imperial era can be seen to coincide with deteriorating and/or unstable climate conditions in the Mediterranean and northern Europe. For example, a series of volcanic eruptions c. CE 235-285 seem to have caused a rapid cooling throughout the Empire, disrupting food production and possibly contributing to the late third century CE monetary crisis (McCormick et al. 2012, p. 186). Increased variability in the Nile floods during this period may have disorganized grain production in Egypt (the imperial breadbasket), which presumably had wider repercussions (McCormick 2013, pp. 76-81). Building on these approaches, the foregoing discussion has explored the potential of looking at aspects of human agency that may rework the negative effects of environmental factors. If we take the RWP into account, we may hypothesize that many of the people who moved into the Murge and Tavoliere might have had to make the most of a more challenging land, under less than ideal climatic circumstances. To be sure, it is important to distinguish between short-term or abrupt environmental changes, and slower ones which allow people to adapt successfully (McCormick 2013, p. 82). This article has arguably dealt with a situation where the lack of abrupt climatic shifts allows us to reflect on a wider spectrum of possible socio-economic and political developments.

To further refine our understanding of human-environment interaction in Republican-period Italy, a few initial steps seem clear. Firstly, we need more data, not only on environmental conditions but on social practices, too. In the absence of excavation, aerial photography and other non-invasive methods such as geophysical survey can shed further light on the nature and distribution of sites (for initial results regarding aerial photography see Goffredo 2006; Goffredo and Volpe 2006). Once the full finds catalogue is published, in-depth analysis of surface pottery and other small finds can provide a higher-resolution picture of the people who occupied the surveyed rural sites, and highlight potential variability at the micro-scale of the single farm (for some preliminary observations, see above). Full data publication might also afford a more detailed chronology of the sites. ${ }^{36}$ Archaeometric analysis of the pottery might provide additional insights into provenance and production (e.g., Amicone 2015). In addition, a better understanding of the funerary sites in the Tavoliere (e.g., site CER16, Figure 3 top) can shed more light on the cultural identity of local communities. As regards coping strategies in the face of socio-environmental challenges, stable isotope analysis may offer an important tool to determine the water status of crops and strategies of water management (Wallace et al. 2015). More research is also needed into the archaeology of storage practices in Daunia (some preliminary data in Goffredo 2010), to identify crop storage capabilities and resistance to drought. Zooarchaeological data has the potential to reveal trends in animal husbandry: certain animals fare better than others in dry environments, so that any changes in the ratio of pigs to goats, for example, can be indicative of adaptive strategies to different or more challenging and arid environmental conditions. ${ }^{37}$ Animal remains might also be considered for potential information about climatic conditions in the past-in view of recent research that explores the possible presence of climate signatures in ancient bones (Dillon et al. 2018). Another tell-tale sign of adaptation to aridity is the digging of deeper water wells, which normally suggests lowering water tables (e.g., Cardarelli 2010, pp. 469-70). Also important is an in-depth analysis of the location of each small rural site or farm, with an eye to river patterns and trajectories, not only in the present but in antiquity, too.

36 For a case-study on key issues concerning black gloss dating see for example (Lambrugo et al. forthcoming) forthcoming on rural fourth-century BCE Sicily.

37 For example, the Terramare civilization in the Po plain witnessed an increase in goat faunal remains at the expense of pigs at a time of increasing aridity in the 12th century BCE (Cardarelli 2010, p. 469). 
Whatever the resilience strategies of the people occupying the small rural sites near Canusium, they seem to have been successful in the long run: $75 \%$ of the sites that appear in the late fourth and third centuries seem to survive into the late first century BCE. Also, whatever may have been happening in the Tavoliere and Murge, the overall impression derived from the historical and archaeological records is one of economic growth rather than decline. In other words, the way in which the rural incomers seem to have responded to social and environmental pressures arguably led to the economic strengthening of the community as a whole, rather than towards its disintegration and decline. It is important to remember that Canusium found itself at the centre of what was perhaps one of the major crises ever faced by Rome and her allies: in 216 BCE, Roman hegemony hung by a thread after the battle at Cannae, just a few miles downriver from Canusium. Presumably, the support of allied communities such as Canusium helped bring about Rome's victory against Hannibal, which contributed greatly to Roman hegemony in the Mediterranean (Eckstein 2006, pp. 264-65; Fronda 2010, p. 330). Despite the possible existence of socio-political tensions within the community, which (as we saw) may account for the movement of people into the Tavoliere and Murge, Canusium managed to prosper and come to Rome's aid - as the story of Busa seems to suggest. ${ }^{38}$ We could therefore be looking at a case where the everyday resilience of displaced common people may have helped secure Roman political and military supremacy. This is a hypothesis that would benefit from further exploration in future research.

Author Contributions: Conceptualization, E.P. and R.S.; methodology, E.P. and R.S.; software, R.S. (Excel database); validation, E.P. and R.S.; formal analysis, E.P. and R.S.; investigation, E.P. and R.S.; resources, E.P. and R.S.; writing — original draft preparation, E.P. and R.S.; writing—review and editing, E.P. and R.S.; project administration, E.P. and R.S.

Funding: Research by Elisa Perego contributing to this article has received funding from the European Union's Horizon 2020 research and innovation programme under the Marie Skłodowska-Curie grant agreement No. 750596.

Acknowledgments: We thank Elena Isayev and Evan Jewell for the invitation to contribute to this journal issue. Ruth Whitehouse, Brandon Lee Drake and two anonymous reviewers kindly commented on earlier drafts. Silvia Amicone and Lars Heinze provided valuable insights into black gloss pottery, while Roberto Goffredo shared his recent work on Daunia and, together with the Journal of Roman Archaeology, allowed us to include modified versions of his survey maps of the Ofanto valley (Goffredo 2010, Figures 11-14). We also thank the Dandara Community for welcoming Scopacasa and Isayev during their 8-year celebrations, and for taking the time to talk to us about the creation of Dandara. Research by Elisa Perego contributing to this article has received funding from the European Union's Horizon 2020 research and innovation programme under the Marie Skłodowska-Curie grant agreement No. 750596.

Conflicts of Interest: The authors declare no conflict of interest.

\section{References}

Amicone, Silvia Rita. 2015. Fourth-century BC black and red gloss pottery from Iasos: A technological approach. In Keramos. Ceramics: A Cultural Approach. Edited by Gül Gürtekin-Demir, Hüseyin Cevizoğlu, Yasemin Polat and Gürcan Polat. Ankara: Bilgin Kültür Sanat Yayınları, pp. 25-39.

Barad, Karen. 2007. Meeting the Universe Halfway: Quantum Physics and the Entanglement of Matter and Meaning. Durham: Duke University Press.

Betts, Alexander, and Paul Collier. 2017. Refuge: Transforming a Broken Refugee System. London: Allen Lane.

Bispham, Edward. 2007. From Asculum to Actium: The Municipalisation of Italy from the Social War to Augustus. Oxford: Oxford University Press.

Black, Richard, W. Neil Adger, Nigel W. Arnell, Stefan Dercon, Andrew Geddes, and David Thomas. 2011. The effect of environmental change on human migration. Global Environmental Change 21: 3-11. [CrossRef]

Boenzi, Federico, Massimo Caldara, Marco Moresi, and Luigi Pennetta. 2002. History of the Salpi Lagoon-sabkha (Manfredonia Gulf, Italy). Il Quaternario 14: 93-104.

Bourdieu, Pierre. 1977. Outline of a Theory of Practice. Cambridge: Cambridge University Press.

38 But see (Fronda 2010, pp. 95-96) for a more nuanced assessment of the Busa episode (above). 
Bras, Anie, Abigaïl-Laure Kern, Georges Eddy Lucien, and Evens Emmanuel. 2016. Poor neighbourhood and natural disaster: The environmental situation of the Cité l'Eternel in Port-au-Prince, Haiti. In Learning from the Slums for the Development of Emerging Cities. Edited by Jean-Claude Bolay, Jérôme Chenal and Yves Pedrazzini. Zurich: Springer, pp. 81-91.

Broodbank, Cyprian. 2013. The Making of the Middle Sea: A History of the Mediterranean from the Beginning to the Emergence of the Classical World. Oxford: Oxford University Press.

Cardarelli, Andrea. 2010. The collapse of the terramare culture and growth of new economic and social system during the Late Bronze Age in Italy. In Le Ragioni del Cambiamento, Atti del Convegno Internazionale (Roma 2006). Edited by Alberto Cazzella, Andrea Cardarelli, Marcella Frangipane and Renato Peroni. Rome: Edizioni Quasar, pp. 449-520.

Compatangelo Soussignan, Rita. 1999. Sur les routes d'Hannibal. Paysages de Campanie et d'Apulie. Paris: Presses Universitaires de Franche-Comté.

Corrente, Marisa. 1997. Canosa di Puglia (Bari), strada vicinale Madonna di Costantinopoli. Taras 17: 43-45.

Crosby, Alfred. 1986. Ecological Imperialism: The Biological Expansion of Europe, 900-1900. Cambridge: Cambridge University Press.

Delano Smith, Catherine. 1979. Western Mediterranean Europe: A Historical Geography of Italy, Spain and Southern France since the Neolithic. London: Academic Press.

Delano Smith, Catherine. 1996. Where was the 'wilderness' in Roman times? In Human Landscapes in Classical Antiquity: Environment and Culture. Edited by G. Shipley and J. Salmon. London: Routledge, pp. 154-79.

De Ligt, Luuk. 2012. Peasants, Citizens and Soldiers: Studies in the Demographic History of Roman Italy, 225 BC-AD 100. Cambridge: Cambridge University Press.

Dench, Emma. 1995. From Barbarians to New Men: Greek, Roman and Modern Perceptions of the Central Apennines. Oxford: Clarendon Press.

Dillon, James T., Sam Lash, Jiaju Zhao, Kevin P. Smith, Peter van Dommelen, Andrew K. Scherer, and Yongsong Huang. 2018. Bacterial tetraether lipids in ancient bones record past climate conditions at the time of disposal. Journal of Archaeological Science 96: 45-56. [CrossRef]

Dipace, Antonio, and Giuseppe Baldassare. 2005. Aree sensibili alla desertificazione nel Tavoliere di Puglia. Giornale di Geologia Applicata 2: 203-9.

Dobres, Marcia-Anne, and John E. Robb. 2000. Agency in Archaeology. London: Routledge.

Dornan, Jennifer L. 2002. Agency and archaeology: Past, present and future directions. Journal of Archaeological Method and Theory 9: 303-29. [CrossRef]

Drake, Brendan Lee. 2017. Changes in North Atlantic Oscillation drove population migrations and the collapse of the Western Roman Empire. Scientific Reports (Online) 7: 1227. [CrossRef] [PubMed]

Eckstein, Arthur M. 2006. Mediterranean Anarchy, Interstate War, and the Rise of Rome. Berkeley: University of California Press.

Finné, Martin, Karin Holmgren, Hanna S. Sundqvist, Erika Weiberg, and Michael Lindblom. 2011. Climate in the Eastern Mediterranean and Adjacent Regions, during the Past 6000 Years-A Review. Journal of Archaeological Science 38: 3153-73. [CrossRef]

Frattaruolo, Francesco, Luigi Pennetta, and Marco Piccarreta. 2008. Desertification Vulnerability Map of Tavoliere, Apulia (Southern Italy). Journal of Maps 4: 117-25. [CrossRef]

Frisia, Silvia, Andrea Borsato, Christoph Spötl, Igor M. Villa, and Franco Cucchi. 2005. Climate variability in the SE Alps of Italy over the past 17000 years reconstructed from a stalagmite record. Boreas 34: 445-55. [CrossRef]

Fronda, Michael P. 2006. Livy 9.20 and early Roman imperialism in Apulia. Historia 55: 397-417.

Fronda, Michael P. 2010. Between Rome and Carthage: Southern Italy during the Second Punic War. Cambridge: Cambridge University Press.

Gardner, Andrew. 2004. Introduction: Social agency, power, and being human. In Agency Uncovered. Archaeological Perspectives on Social Agency, Power, and Being Human. Edited by Andrew Gardner. Walnut Creek: Left Coast Press, pp. 1-18.

Gabba, Emilio, and Marinella Pasquinucci, eds. 1979. Strutture agrarie e allevamento transumante nell'Italia romana. Pisa: Giardini. 
Giddens, Anthony. 1984. The Constitution of Society. Outline of the Theory of Structuration. Cambridge: Polity Press. Giraudi, Carlo. 2014. Coarse sediments in Northern Apennine peat bogs and lakes: New data for the record of Holocene alluvial phases in peninsular Italy. The Holocene 24: 932-43. [CrossRef]

Goffredo, Roberto. 2006. Aerial archaeology in Daunia (Northern Puglia, Italy). New research and developments. In From Place to Space, 2nd International Conference on Remote Sensing in Archaeology, Proceedings of the 2nd International Workshop (Rome 2006). Edited by Stefano Campana and Maurizio Forte. Oxford: Archaeopress, pp. 541-46.

Goffredo, Roberto, and Giuliano Volpe. 2006. Fotografia aerea, archeologia globale e paesaggi antichi della Daunia. Esempi dalle valli dell'Ofanto e del Carapelle. Archeologia Aerea 2: 219-46.

Goffredo, Roberto. 2008. Persistenze e innovazioni nelle modalità insediative della valle dell'Ofanto tra fine IV e I sec. a.C. In Storia e archeologia della Daunia. Edited by Giuliano Volpe, Maria José Strazzulla and Danilo Leone. Bari: Edipuglia, pp. 287-302.

Goffredo, Roberto. 2010. Persistence and change in settlement patterns in the Ofanto valley near Canusium and Cannae (Apulia) (late 4th c. B.C.-1st c. A.D.). Journal of Roman Archaeology 23: 7-33. [CrossRef]

Goffredo, Roberto. 2011. Aufidus: Storia, archeologia e paesaggi della valle dell'Ofanto. Bari: Edipuglia.

Goffredo, Roberto, and Vincenzo Ficco. 2009. Tra Asculum e Herdonia: I paesaggi di età daunia e romana nella valle del Carapelle. In Faragola 1. Un insediamento rurale nella valle del Carapelle. Ricerche e Studi. Edited by Giuliano Volpe and Maria Turchiano. Bari: Edipuglia, pp. 25-56.

Grove, Alfred Thomas. 2001. The 'Little Ice Age' and its geomorphological consequences in Mediterranean Europe. Climatic Change 48: 121-36. [CrossRef]

Halstead, Paul. 1989. The economy has a normal surplus: Economic stability and social change among early farming communities of Thessaly, Greece. In Bad Year Economics: Cutural Responses to Risk and Uncertainty. Edited by Paul Halstead and John O'Shea. Cambridge: Cambridge University Press, pp. 68-80.

Halstead, Paul. 2008. Between a rock and a hard place: Coping with marginal colonisation in the later Neolithic and early Bronze Age of Crete and the Aegean. In Escaping the Labyrinth: The Cretan Neolithic in Context. Edited by Valasia Isaakidou and Peter D. Tomkins. Oxford: Oxbow Books, pp. 229-57.

Harris, William V. 2013. Introduction. In The Ancient Mediterranean Environment between Science and History. Edited by William V. Harris. Leiden: E.J. Brill, pp. 173-94.

Holzhauser, Hanspeter, Michel Magny, and Heinz J. Zumbühl. 2005. Glacier and lake-level variations in west-central Europe over the last 3500 years. The Holocene 15: 789-801. [CrossRef]

Isayev, Elena. 2017. Migration, Mobility and Place in Ancient Italy. Cambridge: Cambridge University Press.

Jones, Sian. 1997. The Archaeology of Ethnicity: Constructing Identities in the Past and Present. London: Routledge.

Lamb, Hubert Horace. 1995. Climate, History and the Modern World. London: Routledge.

Lambrugo, Claudia, Silvia Rita Amicone, and Lars Heinze. Forthcoming. Back to Manfria Farm: Continuity or disruption in the countryside of Gela in the fourth century BC. In Collapse or Survival? Micro-Dynamics of Crisis, Change and Socio-Political Endurance in the First-Millennium BC Central Mediterranean. Edited by Elisa Perego, Rafael Scopacasa and Silvia Rita Amicone. Oxford: Oxbow Books.

Latour, Bruno. 2007. Reassembling the Social: An Introduction to Actor-Network Theory. Oxford: Oxford University Press.

Lloyd, John A. 1995. Pentri, Frentani and the beginnings of urbanisation (500-80 BC). In A Mediterranean Valley: Landscape Archaeology and Annalles History in the Biferno Valley. Edited by Graeme Barker. Leicester: University of Leicester Press, pp. 181-212.

Lloyd, John A., Gary Lock, and Neil Christie. 1997. From the mountain to the plain: Landscape evolution in the Abruzzo. An interim report on the Sangro Valley Project (1994-95). Papers of the British School at Rome 65: 1-57. [CrossRef]

Manning, Sturt W. 2013. The Roman world and climate: Context, relevance of climate change, and some issues. In The Ancient Mediterranean Environment between Science and History. Edited by William V. Harris. Leiden: E.J. Brill, pp. 105-70.

McCormick, Michael. 2013. What climate science, Ausonius, Nile floods, rye, and thatch tell us about the environmental history of the Roman Empire. In The Ancient Mediterranean Environment between Science and History. Edited by William V. Harris. Leiden: E.J. Brill, pp. 61-88. 
McCormick, Michael, Ulf Büntgen, Mark A. Cane, Edward R. Cook, Kyle Harper, Peter John Huybers, Thomas Litt, Sturt W. Manning, Paul Andrew Mayewski, Alexander F. M. More, and et al. 2012. Climate change during and after the Roman Empire: Reconstructing the past from scientific and historical evidence. Journal of Interdisciplinary History 43: 169-220. [CrossRef]

Nobre, Ligia, and Anderson Kazuo Nakano. 2017. On the Slab, Our Architecture under Construction. In Displacement and the Humanities: Manifestos from the Ancient to the Present. Edited by Elena Isayev and Evan Jewell. Special issue, Humanities 6: 62.

Perego, Elisa. 2011. Engendered actions: Agency and ritual in pre-Roman Veneto. In Ritual Dynamics in the Ancient Mediterranean: Agency, Emotion, Gender, Representation. Edited by Angelos Chaniotis. Stuttgart: Steiner Verlag, pp. 17-42.

Perego, Elisa, and Rafael Scopacasa, eds. 2016a. Burial and Social Change in First-Millennium BC Italy: Approaching Social Agents. Gender, Personhood and Marginality. Oxford: Oxbow Books.

Perego, Elisa, and Rafael Scopacasa. 2016b. Introduction. Burial and social change in first-millennium BC Italy: An agent-focused approach. In Burial and Social Change in First-Millennium BC Italy: Approaching Social Agents. Gender, Personhood and Marginality. Edited by Elisa Perego and Rafael Scopacasa. Oxford: Oxbow Books, pp. ix-xxxiv.

Perlman, Janice E. 2010. Favela: Four Decades of Living on the Edge in Rio de Janeiro. Oxford: Oxford University Press. Piva, Andrea, Alessandra Asioli, Fabio Trincardi, Ralph R. Schneider, and Luigi Vigliotti. 2008. Late-Holocene climate variability in the Adriatic Sea (Central Mediterranean). The Holocene 18: 153-67. [CrossRef]

Polemio, Maurizio, and Vittoria Dragone. 2004. La siccità e la disponibilità di acque sotterranee in Puglia. In La siccità in Italia. Atti dei convegni lincei 204. Roma: Accademia Nazionale dei Lincei, pp. 187-93.

Ribeiro, Beatriz, Fernando Oelze, and Orlando Soares Lopes. 2017. A Narrative of Resistance: A Brief History of the Dandara Community, Brazil. In Displacement and the Humanities: Manifestos from the Ancient to the Present. Edited by Elena Isayev and Evan Jewell. Special issue, Humanities 6: 70.

Robb, John. 2007. The Early Mediterranean Village: Agency, Material Culture, and Social Change in Neolithic Italy. Cambridge: Cambridge University Press.

Robb, John. 2010. Beyond agency. World Archaeology 42: 493-520. [CrossRef]

Rosa Filho, Artur. 2012. Os deslizamentos de encostas nas favelas em áreas de risco da "Suíça Brasileira". Acta Geográfica 6: 23-34. [CrossRef]

Sakellariou, Eleni. 2011. Southern Italy in the Late Middle Ages: Demographic, Institutional and Economic Change in the Kingdom of Naples, c.1440-1530. Leiden: E.J. Brill.

Sallares, Robert. 2007. Ecology. In The Cambridge Economic History of the Greco-Roman World. Edited by Walter P. Scheidel, Ian Morris and Richard P. Saller. Cambridge: Cambridge University Press, pp. 13-37.

Scopacasa, Rafael. 2015. Ancient Samnium: Settlement, Culture and Identity between History and Archaeology. Oxford: Oxford University Press.

Scopacasa, Rafael. 2016. Rome's encroachment on Italy. In A Companion to Roman Italy. Edited by Alison E. Cooley. Oxford: Wiley-Blackwell, pp. 35-56.

Skeates, Robin. 2000. The social dynamics of enclosure in the Neolithic of the Tavoliere, south-east Italy. Journal of Mediterranean Archaeology 13: 155-88. [CrossRef]

Small, Alastair B. 1994. Grain from Apulia: The changing fortunes of Apulia as a grain producing area in the Hellenistic and Roman periods. In Tranquillitas: Mélanges en l'honneur de Tran Tam Tinh. Edited by Marie-Odile Jentel. Québec: Université Laval, pp. 543-55.

Snowden, Frank M. 1986. Violence and the Great Estates in the South of Italy: Apulia, 1900-22. Cambridge: Cambridge University Press.

Terrenato, Nicola. 2007. The clans and the peasants. Reflections on social structure and change in Hellenistic central Italy. In Articulating Local Cultures. Power and Identity under the Expanding Roman Republic. Edited by Peter van Dommelen and Nicola Terrenato. Portsmouth: Journal of Roman Archaeology, pp. 13-22.

Volpe, Giuliano. 1990. La Daunia nell'età della romanizzazione: Paesaggio agrario, produzione, scambi. Bari: Edipuglia. Volpe, Giuliano, Angelo Valentino Romano, and Roberto Goffredo. 2015. La Daunia nell'età della romanizzazione. In La Magna Grecia da Pirro ad Annibale. Atti del Cinquantaduesimo Convegno di Studi sulla Magna Grecia. Taranto, 27-30 settembre 2012. Taranto: Istituto per la Storia e l'Archeologia della Magna Grecia, pp. 465-501. 
Wallace, Michael P., Glynis Jones, Michael Charles, Rebecca Fraser, Tim H. E. Heaton, and Amy Bogaard. 2015. Stable carbon isotope evidence for Neolithic and Bronze Age crop water management in the Easter Mediterranean and Southwest Asia. PLoS ONE 10: e0127085. [CrossRef] [PubMed]

Whitehouse, Ruth. 2013. The chronology of the Neolithic ditched settlements of the Tavoliere and the Ofanto valley. In Rethinking the Italian Neolithic. Edited by Mark Pearce and Ruth Whitehouse. London: Accordia Research Institute, pp. 57-78.

Woolf, Greg. 2014. Romanization 2.0 and its alternatives. Archaeological Dialogues 21: 45-50. [CrossRef] 